\title{
Cidadania e clientelismo no Brasil oitocentista: uma análise das práticas políticas em Paracatu/MG
}

\author{
Citizenship and clientelism in Brazilian I80o: an analysis of the political practices in \\ Paracatu/MG
}

\section{Helen Ulhôa Pimentel \\ Laurindo Mékie Pereira \\ Bruna Santana Fernandes*}

\begin{abstract}
Resumo: O conceito e a prática da cidadania transformam-se ao longo tempo, exigindo do historiador análises específicas para casos concretos. Dialogando com a historiografia, analisamos o Livro de Qualificação dos Eleitores de Paracatu-MG, de I876, com o objetivo de traçar o perfil dos cidadãos, as particularidades do sistema eleitoral e as práticas políticas então prevalecentes. Os dados fornecidos e analisados pela pesquisa instigam o leitor a refletir sobre a política brasileira no período, especialmente sobre as redes clientelísticas.
\end{abstract}

Palavras-chave: Cidadania; clientelismo; Paracatu-MG.

Abstract: The concept and practice of citizenship has changed on the time, requiring specific studies for specific cases. Dialoguing with historiography, we analyzed The Book of Qualifications of Electorss of Paracatu-MG, I876, with the aim of identifying the profile of citizens, the particularities electoral system and the current political practices. The result of this search cause the lectors to think about Brazilian politics on that age, specially about the clientelistic webs.

\footnotetext{
" Helen Ulhôa Pimentel é mestre e doutora pela Universidade de Brasília, com estágio doutoral em Coimbra. Professora do Programa de Pós-Graduação em Historia Social da Universidade Estadual de Montes ClarosUnimontes. Laurindo Mékie Pereira é mestre em História pela Universidade Federal de Uberlândia-UFU, Doutor em História pela USP, Bolsista BIPDT/FAPEMIG. Professor do Programa de Pós-Graduação em Historia Social da Universidade Estadual de Montes Claros-Unimontes. Bruna Santana Fernandes é mestranda em História Social na Universidade de Brasília.
} 
Keywords: citizenship; clientelism; Paracatu-MG.

\section{Introdução}

As discussões a respeito de cidadania ainda hoje tomam como eixo condutor as formulações elaboradas por Marshall (1988). Embora deixe claro que sua análise está pautada "mais historicamente do que logicamente" (MARSHALL, I988, p. 9), a formulação mais conhecida do autor diz respeito à tríade direitos civis, direitos políticos e direitos sociais flagrada por ele na história inglesa como um processo sucessivo de conquista da cidadania plena.

A cidadania, para ele, estaria relacionada com a formação do Estado-nação e da centralização do poder. Nesse modelo há um progressivo alargamento da cidadania enquanto desdobramento dos direitos civis em políticos, e depois em sociais, podendo, assim, atribuir a cada um deles um período de formação diferente - direitos civis: século XVIII; políticos: XIX; e sociais: século XX.

A tese de Marshall é convergente com os estudos de Hobsbawm acerca das nações e do nacionalismo. Embora tratando de temas distintos, os dois autores compreendem a formação das nações e da cidadania como processos associados, especialmente no século XVIII e início do XIX. Para Hobsbawm, os primeiros movimentos nacionalistas, a exemplo do caso francês e norte-americano, colocavam o pertencimento à nação como algo produzido por uma escolha histórica, política, sem implicações raciais ou linguísticas. É a fase do nacionalismo cívico. Para ser um cidadão francês, bastava que alguém desejasse sêlo e aderisse às diretrizes político-ideológicas daquele Estado-nação. (HOBSBAWM, 1997, p. I5). Nesse raciocínio, a cidadania e a nação emergem, historicamente, como faces de uma mesma moeda. Ainda conforme Hobsbawm, as nações são construções históricas dos tempos modernos. No decorrer do século XIX, o esforço para inventar as tradições (HOBSBAWM, 1997, p. IO) nacionais foi comum aos diversos países europeus.

A construção das identidades coletivas comporta um complexo processo de invenção de tradições, associação de representações, elaboração de símbolos que facilitam

\footnotetext{
I José Murilo de Carvalho afirma que, no Brasil, devido à maior ênfase dispensada aos direitos sociais, estes precederam aos demais direitos, não seguindo a sequência lógica: civis, políticos e sociais. Confirmando a tese de Marshall, cujas análises sobre cidadania são circunscritas historicamente. (CARVALHO, 2008, p. III2).
} 
a difusão e compartilhamento de um sistema de ideias e imagens com vistas a definir toda uma coletividade nacional, destacando suas épocas áureas, dando, assim, um determinado sentido ao mundo. Comportando crenças, mitos, ideologias, conceitos e valores, o imaginário acaba por construir uma identidade, seja ela social ou individual. (PESAVENTO, 2003, p. 60).

No Brasil, a identificação, até o final do século XIX, estava relacionada com a província, o país era apenas uma construção política, "um ato de vontade movido antes pela mente que pelo coração." (CARVALHO, 2008, p. 77). Foi no período de guerra contra o Paraguai (1865-I870) que surgiram os movimentos criadores de identidade na tentativa de criar um corpo sólido e consistente, pronto para defender sua pátria e seus companheiros. O Estado, de forma deliberada, criou símbolos e mecanismos para atrair a população e forjar um sentimento identitário. Carvalho acredita ter sido este momento histórico o principal fator da criação da identidade brasileira, pois as guerras são as grandes criadoras de identidades nacionais e da cidadania (CARVALHO, 2008, p. 78).

A aceitação de uma entidade abstrata como a pátria como objeto de lealdade suprema, acima da família e de outros grupos primários, só pode constituir fator poderoso de criação de uma identidade nacional. A existência de uma identidade nacional, para além da simples titularidade de direitos, tem sido reconhecida como ingrediente indispensável da cidadania. O próprio Marshall, cujo eixo central de análise era a cidadania como titularidade de direitos, admite este ponto. (CARVALHO, 1996, p. $342)$.

José Bonifácio, personagem central na emancipação do Brasil, já apontava, nos primórdios da história do país independente, preocupação com a falta de coesão social no Brasil e buscava meios de promover um sentimento de reconhecimento e pertencimento nacional. Ao propor a "gradativa" emancipação dos escravos, procurava assegurar a harmonia entre a população livre e escrava. Seu discurso não era de todo benevolente e altruístas para com os escravos, mas, sim, um discurso de caráter liberal, que colocava o sucesso econômico da nação em primeiro lugar.

No entanto, o Brasil que emerge da colonizacão, conforme regulamentado pela Carta de I824, apesar da contradição, manteve o trabalho escravo e as hierarquias sociais a ele associadas. A ausência da palavra escravidão no transcorrer do documento, sendo a questão racial e a escravocrata mencionadas apenas indiretamente, denuncia a maneira 
pela qual eram tratados, ou melhor, sobrepujados os homens "de cor"', isto é, sabe-se apenas da existência de pessoas "de cor" e escravos, no Império do Brasil, como também a sua inferioridade social, devido à aparição das palavras "ingênuos"3 e "libertos", e da legislação referente a eles. Segundo Chalhoub,

[...] não se devia reconhecer, na formulação de políticas de governo, a existência de diferenças de raça ou cor. A posição oficial seria contrária à 'distinção ou divisão por castas', e favorável à promoção do ideal de 'homogeneidade' na constituição da nação. [...] A produção do silêncio sobre a questão racial parecia requisito essencial para forjar o ideal de nação 'homogênea' [...]. (CHALHOUB, 2007, p. 230).

Esse silêncio referia-se também às contradições aparentes entre os direitos civis e políticos, tão "inerentes à cidadania estabelecida pelos novos liberais", como o "longo processo de abolição do cativeiro." (MATTOS, 2009, p. I3). Politicamente, a Constituição estabelecia para funcionar ao lado da monarquia um sistema representativo, organizado por meio de eleições indiretas em dois turnos: o primeiro para a escolha dos eleitores e o segundo para a eleição dos representantes nos níveis provinciais e nacionais.

Ao legislar sobre as eleições, a Carta estabelecia que os votantes, de acordo com o artigo 75, eram homens, maiores de 25 anos, com renda mínima de Ioo mil réis - salvo algumas exceções, pois chefes de famílias, militares, clérigos, bacharéis e empregados públicos tinham o limite mínimo de 2I anos; o que importava era a independência econômica. Eles escolhiam os eleitores e os representantes municipais. Os eleitores, na proporção de um para cada cem residências, eram escolhidos pelos votantes para eleger senadores e deputados, devendo ter renda mínima de 200 mil réis. $\mathrm{O}$ voto era obrigatório e analfabetos podiam votar.

Um dos maiores problemas do regime de voto censitário era a comprovação de renda. Com um sistema socioeconômico predominantemente rural, tornava-se extremamente difícil a medição objetiva dos bens pertencentes a cada homem. Por isso, Hebe Mattos afirma ter sido a construção das listas de qualificação de eleitores uma fonte de "permanente conflito", criando uma esfera de grandes tensões nas eleições locais, que

\footnotetext{
${ }^{2}$ Assim como Hebe Mattos em Raça e cidadania no crepúsculo da modernidade escravista no Brasil, utilizamos a denominação oitocentista "de cor" para referir-nos aos homens negros daquela época. (MATTOS, 2009, p. I8). 3 O substantivo "ingênuo" será exaustivamente mencionado a partir de I87I, quando, objetivando providenciar o gradual processo de abolição da escravidão, o governo promulgou a Lei do Ventre Livre, cujos todos os recém-nascidos de ventre escravo, após aquela data, foram considerados "livres" e "cidadãos" plenos perante a justiça.
} 
foram, mais ou menos, controladas pelo imperador através do Poder Moderador ao garantir a "rotatividade política entre conservadores e liberais." (MATTOS, 2009, p. 24-25).

Para a concepção da época, cidadãos eram aqueles que tinham direito a votar, mas, como podemos analisar, havia uma desigualdade entre cidadãos, pois alguns só poderiam votar no primeiro turno, outros, além de votar no segundo turno, poderiam também ser eleitos. Essa era a legislação vigente no período em que foram qualificados os cidadãos de Paracatu por uma junta de eleitores escolhida pela Câmara Municipal. Essa distinção estabelecia a diferença entre os cidadãos passivos e ativos. Os não-cidadãos não tinham direito ao voto, dentre eles se encontravam as mulheres, os pobres que não possuíam a renda mínima exigida e os não-livres. Os libertos poderiam votar na eleição primária e os ingênuos poderiam ser considerados cidadãos plenos.

De acordo com os padrões da época, a Constituição brasileira era muito liberal. A limitação de renda não excluía a população pobre do direito ao voto, pois grande parte dos trabalhadores ganhava mais de Ioo mil réis por ano. Contudo, alguns problemas são evidenciados devido a um passado recente, e o voto censitário acabava por legitimar as relações entre o acesso à propriedade e direitos políticos. (MATTOS, 200o, p. 34). Carvalho destaca os problemas desse sistema implantado pela Constituição de I824 em uma sociedade recém-saída do sistema colonial montado sobre bases de Antigo Regime. Heranças do período colonial como o escravismo que contaminou todos os extratos sociais, a propriedade rural fechada às leis e o comprometimento com o poder privado, resultaram em um modelo caracterizado pelas relações de compadrio e clientelismo, cujas práticas geraram sérios problemas para o funcionamento do sistema representativo.

Em termos teóricos, para a filosofia liberal, cidadania significa posse de direitos civis e políticos garantidos pela Constituição e não de privilégios concedidos. Apesar da filiação ao liberalismo, o Brasil Império foi palco da coexistência do caráter excludente, hierarquizado e escravista característico do Antigo Regime português com os ideais pregados pela Revolução Francesa, caracterizados pelo estabelecimento de direitos válidos para todos os cidadãos. É a partir dessa nova ordem que iremos dialogar com o documento em foco, o Livro de Qualificações dos Eleitores de Paracatu - I876.

Antes, porém, de examinarmos o Livro de Qualificação, trataremos sumariamente da história, tradições e imagens construídas sobre a cidade de Paracatu/MG. Os paracatuenses gostam, por exemplo, de ostentar orgulhosamente a alcunha de "Atenas Mineira", apesar de não apresentarem estudos capazes de confirmar essa primazia sobre tantas outras cidades. "Peixe saboroso", tradução do termo indígena Pyracatú é usado para 
designar o novo território encontrado. Com o passar dos anos, a palavra "se corrompeu na pronuncia" e tornou-se Paracatu. (GONZAGA, I9Io, p.2). Muitas são as divergências sobre a data de descoberta de Paracatu. Oficialmente, foi no ano de $1744{ }^{4}$

A elevação do arraial à vila, com o nome de Paracatu do Príncipe, dá-se em I798. O título de cidade é obtido em I840, como reflexo "da conjugação de sua importância no espaço e no tempo com a porcentagem de seus habitantes.” (MELLO, 1994, p. 69). Após o boom da mineração em Minas Gerais, Paracatu teria o seu "descoberto" ${ }^{5}$ comunicado à coroa em I744, tornando-se, à época, a mais rica de todas. Por conseguinte, todos os antecedentes e estruturação urbana se deram em virtude do ouro, apesar da presença mais antiga de pecuaristas e bandeirantes. (GONZAGA, I9IO, p. 6I).

Juntamente com o desenvolvimento social e econômico, a cultura letrada também se desenvolve. Em livro editado pela primeira vez em I8I7, o padre Aires de Casal classifica a então chamada Vila do Paracatu do Príncipe de "medíocre e famosa." (I976, p. I77). Em sua descrição ele salienta que havia "aula régia de latim", "três ermidas", que "as casas são térreas, e feitas de madeira", e que "tem decaído muito do seu primeiro esplendor: o povo é pacato, mas indolente: os europeus, por toda parte ativos, são já poucos: gado e mineração fazem a sua riqueza [...]" (p. I77). Conforme o autor, o auge do ouro tinha passado e poucos eram os europeus que haviam decidido ficar ali, mas com toda a dificuldade característica da época, a vila tinha conseguido conquistar a nomeação de professor régio de latim. Além de apontar para certa valorização da cultura erudita, esse fato é um indício de que as lideranças políticas de Paracatu estabeleciam relações com instâncias superiores do poder político no Brasil.

\section{Explorando o Livro de Qualificação de Eleitores}

Instrumento principal de análise das características dos eleitores da paróquia de Paracatu, o Livro de Qualificação de cidadãos foi feito por uma Junta encarregada de elaborar a lista dos aptos a votar. Resultado dos Decretos $n^{\circ}$ 2. 675, de 20 de outubro de I875;

\footnotetext{
${ }^{4}$ Entretanto, Olympio Gonzaga e Oliveira Mello (GONZAGA, I9Io, p. 03-04; MELLO, I994, p. 6I) questionam tal data sob o argumento de que não há fontes confiáveis para a mesma. Os "conquistadores do sertão eram geralmente analfabetos", e os missionários que por lá passaram "pouco ou quase nada escreveram" (MELLO, 1994, p. 6I). No entanto, as informações sobre fazendas de gado ao longo do São Francisco e do rio Paracatu remontam ao século XVI e a trilha que levava a Goiás e passava no centro da atual cidade também remonta ao século XVI. Segundo o historiador Antônio de Oliveira Mello, a região Noroeste de Minas Gerais foi visitada, conhecida e perscrutada desde o final do século XVI. Ele reuniu indícios de que as bandeiras de Domingos Luis Grou (I586-I587), Antônio Macedo (I590) e Nicolau Barreto (I602-I604), palmilharam esta região. (MELLO, 1994, p. 49).

${ }^{5}$ Refere-se às áreas auríferas descobertas. (GONZAGA, I9Io, p. 6I).
} 
e $\mathrm{n}^{\mathrm{o}} 6.097$, de $\mathrm{I} 2$ de janeiro de $\mathrm{I} 876$, a Lei do Terço determinava, no $\mathbb{4 ^ { 0 }}$ do $\operatorname{art.} \mathrm{I}^{\mathrm{o}}$, a obrigatoriedade das listas dos votantes:

$\$ 4^{\underline{o}}$ - As listas geraes, que as Juntas parochiaes devem organizar, conterão, além dos nomes dos cidadãos qualificados, a idade, o estado, a profissão, a declaração de saber ou não lêr e escrever, a filiação, o domicilio e a renda conhecida, provada ou presumida; devendo as Juntas, no ultimo caso, declarar os motivos de sua presumpção, e as fontes de informação a que tiverem recorrido. (Decreto $\mathrm{n}^{\circ}$ 2675, $1875, \mathrm{p}$. 02).

Mais do que determinar a execução das listas, essa lei dividia os cargos eletivos em dois terços para a maioria e um terço para a minoria, causando muito descontentamento por parte dos eleitores. No glossário on-line do Tribunal Superior Eleitoral, TSE, encontramos a seguinte definição da lei, da qual podemos extrair uma justificativa para tal insatisfação:

[...] os partidos geralmente não se apresentavam sozinhos, e sim em coligações. A coligação que vencesse, ganhando os dois terços, seria formada de elementos de mais de um partido. E, nas câmaras, seria difícil garantir que a unidade obtida nas eleições seria mantida no Plenário. Assim, 'maioria' era um conceito que se relacionava mais com uma vitória eleitoral do que propriamente com uma organização de governo. (Brasil, 20II).

Para conseguir a "maioria", os candidatos irão se debruçar em busca de fiéis clientes votantes, criando variados laços com seu eleitorado. Esse emaranhado de trocas de favores começou com a autoridade máxima, o Imperador, cuja estratégia era a rotatividade dos partidos Conservador e Liberal. Por meio das eleições, surgia uma rede que ligava todos, desde aquele que estava no topo, àquele que estava na base, configurando uma prática que se tornaria ainda mais sólida na Primeira República, quando as relações de compromissos permeavam todos as instâncias do jogo político. (JANOTTI, I98I; QUEIROZ, I975).

Controlada pelo grupo que estivesse no poder, à Assembleia Paroquial competia a chamada dos votantes pela lista de qualificação, e a apuração das cédulas recebidas. Logo, a Junta de qualificação decidia quem poderia ser votante ou não. A sustentação dessa afirmativa se encontra no demasiado número de qualificações consideradas ignoradas, e de 
informações contestáveis analisadas no Livro de Qualificações de Eleitores de Paracatu. Portanto, reconhecendo quem estava na organização do processo eleitoral, consequentemente, sabia-se quem seria o vencedor.

Nos documentos analisados, encontra-se a primeira qualificação que data de I874, constando apenas o nome, a idade, o estado civil e a ocupação. A partir do decreto 6097 de I2 de janeiro de I876, foi feita uma atualização dessa qualificação e foram lançados nome, idade, profissão, estado civil, sabe ler ou escrever, filiação, domicílio, renda e uma coluna para observações onde aparecem informações sobre falecimento, mudança de endereço da pessoa e, em um único caso, dizendo ser o cidadão liberto.

Como naquele momento havia votantes e eleitores, ou seja, alguns mais e outros menos considerados social e economicamente, o cruzamento desses dados nos dá uma noção do funcionamento da sociedade e da cidadania. Interessa saber quem era considerado cidadão a partir do conceito de sistema representativo adotado pelo Brasil em sua primeira Constituição e que contornos essa cidadania adquiria. A partir dos dados coletados no Livro de Qualificação de Eleitores, busca-se entender a forma como foi constituída a Junta revisora de qualificação, que tipo de cidadão fazia parte dela e as dificuldades relatadas para a execução da tarefa. Ao longo do texto, analisaremos alguns dos dados presentes no Livro de Qualificação e, a partir desses dados, abordaremos temas recorrentes e caros a este período, como a escravidão, a Reforma Eleitoral de I88I e o clientelismo. ${ }^{6}$

\section{Saber ler ou escrever}

Muitos estudos mostram que a alfabetização era a exceção e não a regra no Brasil oitocentista. No entanto, nossas análises do Livro de Qualificação apontam uma grande porcentagem dos que "sabiam" ler e escrever. Conforme a primeira ata de $1876,64,42 \%$ dos eleitores sabiam ler. Todavia, esse dado muito nos instiga, pois, cabe um questionamento sobre a forma de avaliação feita para tal classificação. Seriam esses dados, de fato, verdadeiros? A cidade então faria jus ao codinome de "Atenas Mineira"?

"Ignora-se", "não", e espaços vazios - não preenchidos -, são outras respostas registradas no Livro referente à classificação "Sabe ler ou escrever". Os números são

\footnotetext{
${ }^{6}$ Trabalhamos com os dados da primeira ata das eleições de I876, iniciada em 02 de abril de I876, a partir do decreto de janeiro do mesmo ano, a qual contém II89 eleitores. Após essa primeira qualificação, foi elaborada outra lista com 1555 nomes, aparecendo moradores de fazendas e distritos pertencentes à paróquia de Paracatu, à qual foram feitos acréscimos de pessoas que reuniam as condições e não constavam ali (onze ao todo).
} 
curiosos: $28,68 \%$ têm como ignorada essa aptidão; 5,21\% não sabem ler ou escrever; e, o restante, I,68\% não contém nenhum dado - muitos devido ao falecimento. Nosso primeiro questionamento recai sobre o significado, para aquela época, de ler e escrever. Ora, como falamos antes, o índice de analfabetismo durante o Império no Brasil era altíssimo, e Paracatu não poderia apresentar desempenho diferente. De acordo com os dados apresentados pelo Instituto Brasileiro de Geografia e Estatística no Censo de I872, no Brasil o percentual de pessoas analfabetas com 5 anos ou mais era de 82,3\%. Em Minas Gerais, as pesquisas apontaram que $85,6 \%$ da população era analfabeta, (FERRARO; KREIDLOW, 2004, p. 5 e I6) dado este incompatível com os números apresentados pelo Livro de Qualificação.

Quais eram os critérios para essa avaliação? E por que se ignorava, em muitos casos, essa classificação? Sabemos que, no geral, ensinava-se apenas a desenhar o nome, habilidade já tida como suficiente para o alistamento. Isso ocorre, principalmente, quando assinar torna-se condição e exigência para o voto, a partir da lei de I88I. Mas essa possível explicação para os dados perde força em se tratando de documento de i876 como a ata que ora analisamos.

Outra questão: Será que o demasiado número de "ignora-se" está relacionado à flexibilidade e à não obrigatoriedade de alfabetização durante o período analisado? Outro indício que também nos aponta para a compreensão da flexibilidade do controle de qualificação dos votantes é a formação da Junta Paroquial, que buscava garantir o controle e a derrota da oposição.

Se somarmos os números dos que tiveram essa classificação ignorada com os que foram considerados não aptos à leitura ou à escrita, teremos um total de 33,89\%, isto é, 403 votantes, dos II89, que, hipoteticamente, não sabiam ler ou escrever, e que estariam fora das eleições de I88I, devido à reforma eleitoral, cujo direito de voto foi retirado daqueles que não eram alfabetizados. Contudo, esses dados são hipotéticos, pois, ainda não se sabe ao certo quais eram os critérios para tal seleção, ${ }^{7}$ tornando-os duvidosos, visto que a alfabetização ainda não era obrigatória. Sem contar que "ignora-se" não significa literalmente "não", deixando, assim, algumas brechas e dúvidas.

A nova legislação escravista de I87I (Lei do Ventre Livre) trouxe novos caminhos aos escravos, assim como esperança para os libertos, dando-lhes novas estratégias de luta. Com a aprovação dessa lei, colocava-se em questão não somente o fim da escravidão, mas

\footnotetext{
${ }^{7} \mathrm{O}$ artigo $\mathrm{I}^{\mathrm{o}}$, parágrafo $4^{\mathrm{o}}$, inciso I, NI, da Lei do Terço, apenas menciona a maneira pela qual deverá ser reconhecida e comprovada a renda dos votantes e eleitores, não fazendo menção ao modo de avaliação dos alfabetizados.
} 
também a discussão sobre cidadania na monarquia. Até a instituição da lei, os homens livres "de cor" "precisavam ser socialmente reconhecidos como tal", limitando seu campo de atuação. Após I871, "era o senhor que precisava apresentar a matrícula de seu escravo. Sem ela, qualquer pessoa 'de cor' era juridicamente livre”. Ao mesmo tempo em que a matrícula dava o direito à indenização ao direito de propriedade dos senhores, também "rompia com a associação legal entre cor e suspeita da condição de escravidão." (MATTOS, 2009, p. 22-23). Portanto, pode-se dizer que se atenuava a situação social do negro no Brasil. Eles tinham agora uma lei que os tornava cidadãos possuidores legais dos benefícios da nação, embora limitados. A relação entre raça e cidadania se modificará de agora em diante, pois a questão da abolição reportará igualmente à definição de cidadão constituída pela Constituição.

Nesse ínterim, "libertos" e "ingênuos" seriam considerados cidadãos. Entretanto, a condição de cidadão ativo politicamente lhes será vedada por ocasião das leis restritivas. De acordo com Chalhoub, os trabalhadores "de cor" participavam do sistema eleitoral "na qualidade de massa de manobra, fornecendo capangas e dependentes às pencas num processo inteiramente controlado pelas classes dirigentes e proprietários." (CHALHOUB, 2007, p. 220-22I).

Analisando a Reforma eleitoral de I88I e algumas de suas implicações, o autor explica:

Na segunda metade do século XIX, o problema era definir os direitos políticos dos descendentes de escravos. Após a lei de I871, havia o temor de que os filhos de escravas nascidos livres em virtude da lei viessem a adquirir cidadania plena ao atingir a maioridade, tornando-se agentes formais do mundo político. A solução à brasileira desse problema [...] foi elidir critérios raciais de exclusão e passar a exigir [...] a capacidade de ler e escrever para a qualificação de eleitores (Lei da Reforma Eleitoral de I88I). (CHALHOUB, 2007, p. 220).

Nesse momento, entra em cena o grande temor das elites: a população escrava e seus remanescentes. O "silêncio ensurdecedor" na Constituição a respeito das diferenças raciais prova o não reconhecimento da existência de diferenças de raça ou cor. Com a inserção dos negros à comunidade nacional como cidadãos, crescia o medo e as reprovações das elites. A reforma eleitoral de I88I, instituindo a eleição direta e visando aumentar a representatividade eleitoral, é mais uma das estratégias das classes dirigentes 
para manter o controle social. Ao elevar a renda do cidadão ativo e ao instituir a obrigatoriedade da alfabetização, o governo restringe ainda mais o direito ao voto. Assim, cada vez mais, a Constituição se torna antidemocrática.

São esses silêncios reformadores, ora aqui ora ali, que nos instigam cada vez mais. A ausência de uma coluna, cuja nomenclatura poderia ser "cor", na lista de qualificação, remete-nos a muitos questionamentos. Um deles é, qual seria o motivo para a exclusão dessa "qualificação"? Ignorar a presença dos homens "de cor" não era muito bem a intenção, pois o voto censitário já demonstrava para quem o voto estava sendo restrito. Ora, também sabemos que a intenção dessa ausência não era inserir os negros na sociedade.

\section{"Elege-me tu que te elegerei eu"}

A expressão reproduzida nesse subtítulo, utilizada por Joaquim Nabuco para denunciar a realidade do sistema eleitoral brasileiro do século XIX diz, em poucas palavras, o verdadeiro sentido das trocas políticas daquele tempo. (NABUCO, apud GRAHAM, I997, p. I23). As relações clientelares tão presentes em muitos trabalhos que analisam as relações sociais estabelecidas no período colonial - e que teriam sido mantidas durante todo o período imperial brasileiro, e avançado para o período republicano - foram analisadas pela historiografia mais antiga de uma maneira e pela historiografia mais recente de outra.

Alexandre Mendes Cunha faz um percuciente balanço desse debate. Para ele, "a centralidade da ideia de redes clientelares à compreensão da composição de forças políticas e econômicas e da própria conformação das elites na América portuguesa parece [...] inquestionável." (2006, p. 242). Entretanto, os significados dessas redes precisam ser devidamente diferenciados para que não se perca de vista os diferentes tempos históricos em análise, a saber, os séculos XVIII e XIX.

$\mathrm{Na}$ acepção proposta por Cunha, as práticas clientelistas do século XIX sucedem, de forma geral, as redes clientelares do período colonial. No entanto, ele é claro em destacar como as diferenças históricas dos dois períodos incidem no debate sobre o tema. A experiência da colônia se insere na chamada cultura política do Antigo Regime marcada pelos princípios do dom, dádiva e reciprocidade e, a partir desta ótica, são tratadas como legítimas pelos analistas. $\mathrm{Na}$ nova conjuntura oitocentista, as práticas, embora semelhantes, se inscrevem em um contexto de país independente, regido por uma Constituição liberal. (CUNHA, 2006). Nessas circunstâncias, as práticas clientelistas se 
revelam como sistema político e emergem nos textos dos pesquisadores em tom sempre crítico, às vezes até pejorativo.

De modo geral, o conceito mais utilizado, e que bem resume as relações de clientelismo, refere-se a uma trama de relações entre "atores políticos que envolve concessão de benefícios públicos”, como empregos, benefícios diversos e regalias, em troca de apoio político, isto é, em troca de voto. (CARVALHO, I997, p. 2). Seu conteúdo também varia com o tempo, podendo aumentar e diminuir ao longo da história, e mudar de parceiros. A ampla duração e a maior pluralidade de casos das relações clientelísticas na história são resultados de vários condicionantes traçados ao longo do tempo, que fazem das relações de dependência uma regra. Essas relações, contudo, precisam ser analisadas e inseridas em um processo que combina ruptura e continuidades, cumprindo função essencial na reprodução de mecanismos de exclusão social. (CUNHA, 2006, p. 240).

Conforme o mesmo autor, ainda que entendido como um fenômeno de duração alargada, devemos tomar o cuidado de não caracterizarmos o clientelismo como um "sistema político". Nas suas palavras:

[...] o clientelismo não compõe de forma alguma, em uma análise política alongada, um 'sistema político', e não raro responde a formas por demais variadas, em que se estabelecem as estratégias de ação em conjunturas de forças políticas assimétricas; daí a idéia de não um, mas vários clientelismos. (CUNHA, 2006, p. 240).

Aceitando como base o caráter assimétrico do fenômeno político do clientelismo, Luiz H. N. Bahia, segundo D’Avila (2003, p. I53), classifica as trocas políticas como "trocas políticas assimétrico-clientelistas", as quais possuem, além da assimetria dos acessos aos centros de poder e controle, uma hierarquia vertical, não formal, particular e difusa; espaços não formalizados pela lei; demandas fragmentadas; trocas recíprocas e benéficas entre os atores políticos.

A partir desses elementos, podemos afirmar que o clientelismo está relacionado à exclusão e acesso aos bens e serviços não regulados pela ordem jurídica, não havendo, portanto, nenhuma garantia legal, nenhum direito. Cientes dessas "limitações", os atores dessa trama "aceitam", "jogam", "toleram" as relações sociais clientelistas. Apoio político, lealdade e benefícios patrimoniais são os principais "objetos" de troca das redes então instituídas. 
Desse modo, como já mencionado acima, o clientelismo não pode ser tomado como um sistema político específico, pois contém uma duração maior; é constituído por uma pluralidade de casos, além, obviamente, do seu caráter flexível. Sua importância para o tema ora analisado é indiscutível. A nossa abordagem neste trabalho privilegia um olhar sobre as relações sociais e políticas, buscando entender a linha que une a rede de relações políticas estabelecidas no final século XIX, em especial, no processo eleitoral de Paracatu.

As disposições da Constituição de I824 podem ser observadas como "reconhecimento e legitimação de privilégios senhoriais e de hierarquias sociais herdadas do Império Português” (MATTOS, 2000, p. 34), pois ao invés de emanar do povo - maior representação social da nação - era "concedida pela magnanimidade" do soberano. O voto censitário é a mais clara e pura evidência da legitimação de poder entre as relações de acesso à propriedade e direitos políticos daquela época. A Carta de I824 "trazia em seu bojo limitações profundas [também] em relação aos direitos civis." (NEVES, 2009, 195-196). Com o poder moderador constituído, o jogo político típico do século XIX, no Brasil, começava com o próprio imperador. O predomínio das vontades particulares dos chefes de famílias, em detrimento de um poder público, em larga medida, inoperante na América portuguesa e que teria tido continuidade durante o Império, constituiria nas relações de compadrio e clientelismo. Como analisa Sérgio Buarque de Holanda,

[...] foi sem dúvida o [círculo] da família aquele que se exprimiu com mais força e desenvoltura em nossa sociedade. E um dos efeitos decisivos da supremacia incontestável, absorvente, do núcleo familiar - a esfera, por excelência dos chamados 'contatos primários', dos laços de sangue e de coração - está em que as relações que se criam na vida doméstica sempre forneceram o modelo obrigatório de qualquer composição social entre nós. Isso ocorre mesmo onde as instituições democráticas, fundadas em princípios neutros e abstratos, pretendem assentar a sociedade em normas antiparticularistas. (HOLANDA, 20I0, p. I46).

Influenciado pelas concepções weberianas do Estado e da burocracia (WEBER, 1999), Holanda critica fortemente os condicionamentos privados sobre o poder público no Brasil. "Os laços de sangue e de coração" seriam as bases da estrutura privada e excludente de uma sociedade altamente hierarquizada e escravocrata, fornecendo-nos um "modelo 
obrigatório de qualquer composição social". O "homem cordial"8 e a maneira pela qual ele se insere no mundo é mais uma das demonstrações de "nossa incapacidade de realização da cidadania e materialização de um Estado racional-legal capaz de romper com os vínculos personalizados de dependência e submissão à esfera privada." (VELLASCO, 2009, p. 8I-82). O caráter antidemocrático dessas práticas é evidente. Como afirma Vellasco, “as relações de aliança, submissão e dominação clientelística" fornecem a "chave para o entendimento das imperfeições históricas da realização da cidadania entre nós." (VELLASCO, 2009, p. 82).

Parte desse processo, importante na formação de nossa sociedade, teria sido deflagrada pela Lei de Terras (I8 de setembro de I850), que, na opinião de Hamilton Monteiro,

[...] consagrava o latifúndio, base da classe dominante brasileira, e impedia a formação de um campesinato proprietário de terra; no lugar deste, ampliou-se a categoria de posseiros ou agregados, que serviria de reserva de mão-de-obra e de massa de manobra política [...] A lei que foi aprovada só admitia a aquisição de terras por compras, e, pela forma como se fez o registro das propriedades, os grandes proprietários rurais incorporaram vastas extensões de terra pública ao seu domínio. (MONTEIRO, I986, p. 39-40).

Essas relações foram mantidas de maneira muito forte no período imperial, como aspecto remanescente do colonial. Sua estruturação a partir da Constituição de I824 se fará através do controle eleitoral, que terá como base relações clientelistas que buscarão trocar empregos por votos, por exemplo; recrudescendo, dessa forma, a soberania das elites locais. Será, na visão de Ivan de Andrade Vellasco, em uma "estrutura social igualmente marcada pela preponderância do poder privado e pela dependência propositiva dos dominados" (2009, p. 76) que o clientelismo encontrará terreno fértil para se desenvolver e frutificar. As redes “clientelares", na opinião de deste autor,

\footnotetext{
8 "A lhaneza no trato, a hospitalidade, a generosidade, virtudes tão gabadas por estrangeiros que nos visitam, representam, com efeito, um traço definido do caráter brasileiro, na medida, ao menos, em que permanece ativa e fecunda a influência ancestral dos padrões de convívio humano, informados no meio rural e patriarcal. Seria engano supor que essas virtudes possam significar 'boas maneiras', civilidade. São antes de tudo expressões legítimas de um fundo emotivo extremamente rico e transbordante." (HOLANDA, 20IO, p. I46-I47).
} 
[...] não se resumiam a relações de dominação e submissão, mas se fundavam em cadeias de reciprocidade geradoras das 'redes de interdependência' que produziam e alicerçavam as 'redes de poder'. A lógica das relações 'clientelares' não era, portanto, apenas a do 'interesse' nem a do controle unilateral dos dominantes, mas antes uma lógica ordenadora, naturalizada como visão de mundo e que estabelecia um jogo de reciprocidades, direitos, deveres e compromissos que [...] constituíam o cimento de uma ordem social que, de resto, seria insustentável. (VELLASCO, 2009, p. 88).

Também analisando as relações clientelísticas no Brasil, foi (e ainda é) de grande contribuição para a historiografia brasileira, a obra de Richard Graham, Clientelismo e política no Brasil do século XIX. Sua análise da política imperial patriarcal brasileira o faz vislumbrar o grande peso das ligações de dependência e subordinação. Para ele, o clientelismo "constituía a trama de ligação da política no Brasil do século XIX e sustentava virtualmente todo ato político." (GRAHAM, 1997, p. I5. Grifo nosso). A generalização dessa afirmativa, assim como vários trechos de sua obra, o fará ser alvo de várias críticas, em especial de José Murilo de Carvalho. Para este, os problemas surgem quando Graham insiste em "trabalhar o tempo todo com a noção de clientelismo, de relações patrão-cliente e, mais ainda, quando considera, sem justificativas, o Estado como sendo a clientela das elites locais, e não o contrário, o "senhoriato rural" sendo a clientela do Estado." (CARVALHO, I997, p. 5-6). É a falta de consistência dos argumentos de Graham que fazem Carvalho questioná-lo, assim como a tese da hegemonia dos grandes proprietários sobre o aparelho de Estado.

Ao deixar de analisar essas relações como um movimento contínuo e passível de mudança, Graham acaba por "assumir a patronagem como um fenômeno de longa duração e [...] como grande explicativo não apenas do Império, mas de toda a história brasileira" (CUNHA, 2006, p. 234), levando muitos leitores a analisar a patronagem como uma particularidade ibérica legada a suas colônias.

O baluarte das relações clientelísticas era o controle eleitoral juntamente com as trocas de benefícios entre atores sociais desiguais. "Clientelismo significava tanto o preenchimento de cargos governamentais quanto a proteção de pessoas humildes, mesmo os trabalhadores agrícolas sem terra." (GRAHAM, I997, p. I6). Eram exatamente as eleições que testavam e recrudesciam a liderança dos chefes locais. Com a preocupação de se 
estabelecerem no poder, os políticos do século XIX valiam-se de todas as formas para ampliar suas redes de clientelismo, gastando grande parte de sua energia neste ímpeto.

O clientelismo era apenas uma face do jogo social e político. As intrigas, incluindo aquelas de caráter violento, também compunham o teatro encenado pelos partidos Liberal e Conservador, afetando o cotidiano dos moradores, como se evidencia no caso de Paracatu-MG. Com a proteção dos chefes políticos, "malfeitores" espancaram padres, roubaram urnas eleitorais e cometeram homicídios. (GONZAGA, I9IO, p. 43). Exemplo das relações entre chefes locais e gabinetes é a revogação das eleições de I849 desta mesma cidade,

Os chefes do partido conservador, contando com o apoio do celebre juiz de direito dr. Theodosio Manoel Soares de Souza, annularam as eleições municipaes desse anno, nas quaes os liberaes tiveram maioria tanto na Camara como nos Districto e praticaram desatinos, sendo presos diversos chefes do partido contrario, [...]. (GONZAGA, I9IO, p. 44).

Ainda de acordo com Gonzaga, nas eleições de I860, Capitão Bello, "homem vingativo e violento", buscando sua hegemonia local, roubou com seus "jagunços armados" a urna de eleições abrindo-a "a machado" e que, apesar de processado pelo Juiz de Paz, o padre José de Moura Barbosa, e excomungado por tê-lo espancado, nada de mais lhe aconteceu. (GONZAGA, I9IO, p. 45). Esses dois casos referentes à cidade de Paracatu são exemplos que nos ajudam a compreender como era a vida política e social desta cidade. Além da troca de favores livre, havia também a imposição cruel das vontades dos chefes locais de forma violenta e direta. A fim de garantir a sua vitória e a do partido, tudo era lícito:

Os que estavam no poder não podiam se dar ao luxo de perder eleições porque a medida de um homem dependia do tamanho de seu grupo de seguidores e uma eleição perdida reduziria visivelmente essa comitiva [...] ser rejeitado por seus próprios seguidores indicava um fracasso de liderança, força, caráter, enfim, da própria clientela. (GRAHAM, 1997, p. II2).

E para conquistar seus benefícios, cada um, cliente e patrão, a seu modo, demonstrava sua lealdade. 
Mais do que uma exclusão, as eleições eram uma forma de diferenciação. Os clientes demonstravam lealdade, obediência, reconhecimento; os patrões reafirmavam seu dom de proteção. Por tudo isso o espetáculo devia e podia ser amplo, bem como essencialmente público, quase uma festa, embora uma festa sempre tensa e que podia ser também violenta. (LIMA, I999, p. 3).

Parece-nos válido, portanto, afirmar que a chave-mestra do clientelismo se encontra exatamente na manutenção das desigualdades engendradas na sociedade, conforme feliz síntese de Cunha: "as relações clientelísticas mudam ao longo do tempo para deixarem iguais as relações sociais assimétricas que estão (e são) na sua própria origem." (CUNHA, 2006, p.24I).

\section{A cidadania em Paracatu no século XIX}

Em que medida pode-se falar em cidadania nessa sociedade que acabamos de descrever? Diferente do conceito atual, cidadania no Império relacionava-se intrinsecamente com o direito ao voto. $\mathrm{O}$ direito de votar naquele tempo estava associado a certos privilégios. Ter a renda igual ou acima da estipulada pela lei para votar era sinônimo de status social, por isso, a existência de diferentes leis determinantes sobre os critérios para ser votante e eleitor. A hierarquia construída a partir da Constituição excluía os que consideravam inferiores e indiferentes para a constituição da nação. Escravos, miseráveis e mulheres constituíam a parcela da população que em nada ajudava a nação; daí surgir a necessidade de excluí-los das eleições, isto é, retirar o direito de intervenção direta desses sujeitos, consolidando a sua condição de sujeitos passivos.

Eram as eleições que testavam e ostentavam as lideranças locais. A prática do favor, combustível do clientelismo, era o que movia todo o aparato eleitoral local. Os líderes políticos nomeavam, após as eleições, como forma de recompensa, aqueles que haviam sido fiéis a eles e ao partido. Muitas vezes, os favores eram trocados antecipadamente com aqueles que ajudariam nas eleições. (GRAHAM, 1997, p. I3I). Assim, os critérios de comprovação de renda eram muitas vezes deixados de lado, pois a Junta qualificadora, almejando continuar no poder, estabelecia quem, de fato, poderia votar. O caráter fraudulento das eleições é objeto de várias críticas, em especial quando a oposição perdia a eleição. Até os próprios vencedores das eleições assumiam as fraudes. 
Como Paulino José Soares de Souza (depois visconde de Uruguai) escreveu em particular para um amigo, em I852: 'A oposição disputou aqui a eleição com grande fúria, e com grande meios. Batemo-la completamente porque estamos no governo. Se ele estivesse no governo, teria vencido completamente [...]. Assim é o sistema'." (GRAHAM, I997, p. II4).

Casos como esse e do Capitão Bello eram correntes no período imperial. Desse modo, a situação se serve das estruturas do Estado para garantir a eleição. Nas palavras de Graham: "o governo procurava influenciar os votantes nomeando os que eram capazes de usar da força contra eles: em primeiro lugar os chefes de polícia, delegados, subdelegados e inspetores de quarteirão.” (GRAHAM, I997, I24). Por sua vez, as oposições sempre denunciavam esta prática, mas a repetiam tal como denunciam uma vez conquistado o poder.

Difundidas entre todos os grupos políticos, as práticas clientelistas ganhavam contornos de legitimidade. Nesse sentido, os agrupamentos políticos locais apresentam mais semelhanças do que diferenças. Ambos - oposição e situação - eram clientelistas. A diferença entre eles está no desigual domínio sobre os recursos de poder.

Apesar de suas especificidades, a exemplo do possível maior número de alfabetizados, as relações políticas em Paracatu-MG estão, pois, dentro do "padrão clientelista" nacional. As raízes patriarcais do município também pesavam na formatação dessas relações prevalecentes no século XIX. Oliveira Mello ao nos "revelar" Paracatu, afirma o caráter patriarcal dessas terras mineiras citando Salles (I963, p. 65):

A formação social das zonas agropecuárias, mesmo aquelas que foram antes mineradoras, como Paracatu, que atravessou os dois ciclos - é de acentuada tendência patriarcal. Imperava o paternalismo, a amizade protetora entre o patrão e o vaqueiro. Também este espírito patriarcal perdurou até o século XX. (SALLES, apud MELLO, 1994, p. 55).

Tão caras ao período aqui analisado, as relações de patriarcalismo e clientelismo se faziam presentes também em terras mineiras, acentuando o caráter hierárquico da sociedade. Poucos eram aqueles que tinham condições monetárias de exercer poder numa sociedade em que o dinheiro era o seu prestígio e dom. Se considerarmos, pela análise do Livro de Qualificação, os homens possuidores de renda maior que um conto de réis, em 
Paracatu, teremos um total de apenas 85 cidadãos, o que significa 7,15\% da população votante paracatuense. Agora, restringindo essa análise para os cidadãos com renda acima de três contos e quinhentos mil réis, calculamos um total de 13 homens possuidores das maiores riquezas da cidade, ou seja, aproximadamente I,I\% desta população representava a elite local, havendo, portanto, uma acentuada desigualdade na distribuição de renda.

Instigantes resultados nos fizeram correlacionar profissão e renda. Analisados os cidadãos com renda superior a um conto de réis (7,15\% dos votantes), encontramos os seguintes números: 36 eram negociantes; I6 lavradores (com exceção de um cidadão com renda de dois contos de réis, o restante tinha renda de um conto de réis); Io fazendeiros; 6 empregados públicos; 3 magistrados; 3 proprietários; 2 advogados; 2 médicos; I dentista; I alfaiate; 2 clérigos $^{9}$; I agência (que agencia, exerce atividade como de corretor); I sapateiro e I cidadão com o campo profissão deixado em branco. Dessas informações, extraímos que os homens possuidores das maiores rendas eram cidadãos com profissões urbanas, isto é, aproximadamente $68,23 \%$ tinham empregos urbanos, além de propriedades urbanas. Essa desigualdade socioeconômica aparente se revela ainda nas médias de renda: a renda média do Livro de Qualificação é de 385\$204 mil réis; já a média daqueles 7,I5\% é de 2.056\$ooo.

Esses dados demonstram a disparidade social que havia em Paracatu naquela época, contribuindo para a compreensão do divórcio existente entre o funcionamento prático do regime e sua filiação liberal-democrática. A reforma eleitoral de I88I, visando maior representatividade, instituiu a eleição direta. Como resultado concreto, ao aumentar a renda mínima do cidadão ativo, diminuiu a participação política de grande parte da população.

A combinação de forte desigualdade social, restrição dos direitos civis e políticos a uma parcela da população e um sistema eleitoral fundamentado nas relações de clientelismo, parecia integrar um conjunto maior, forjando um "contrato social implícito" (VELLASCO, 2009, p. 89) que regia a sociedade brasileira de então, modelada em boa medida pela diluição das fronteiras entre o público e o privado.

\section{Considerações finais}

O conceito de cidadania vigente estava ainda muito ligado ao voto, ou seja, cidadão era quem exercia a cidadania política, que votava ou poderia ser votado. É a partir desta visão de cidadania que, cada vez mais, os grandes proprietários ocuparam seu espaço

\footnotetext{
9 A maior renda registrada no Livro de Qualificação, de seis contos de réis, diz respeito ao Cônego Miguel Archanjo Torres, na época, com 65 anos de idade, pertencente às "Ordens". (APMOMG).
} 
dentro da instituição pública, e, consequentemente, a população percebeu o valor que o voto ganhou nesta fase, trazendo consigo oportunidades de barganha, isto é, o voto seria mais um instrumento de negociação para os eleitores.

Para Carvalho, essa estrutura criou corpo e se desenvolveu espantosamente, e, diferentemente do que muitos acreditam, os brasileiros, antes afastados da vida pública, saíram do status de "ignorante" e passaram a se relacionar com o Estado (cada um a sua maneira), isto é, grande parte da população brasileira que durante o período colonial se mantinha afastada da vida pública, saiu do seu paroquialismo e passou a se relacionar com o poder público. A eleição, trazendo consigo o voto, foi um dos grandes exemplos dessa mudança. Nas palavras de José Murilo de Carvalho "pode-se dizer que muitos se tornaram conscientes da presença do Estado; em alguns foi despertada a consciência da nação como comunidade de pertencimento." (CARVALHO, I996, p. 355).

Estudar o caso específico de Paracatu contribui para lançar luz sobre o tema da cidadania vigente no período analisado, apontando similitudes e diferenças na sociedade e nas práticas políticas no Brasil do século XIX. Longe de pertencer a uma classe dominante, o povo constituía a parcela dos votantes. A Junta de Qualificação, controlada pelo grupo que estava no poder, decidia quem votava. Era a necessidade dos chefes locais em constituir uma clientela consistente que determinava as interpretações da lei sobre as exigências das qualificações. Havia, conforme Lima, "um complexo jogo entre ações extralegais - pela força ou pela fraude - e a legalidade. Ostentar uma força [...] seria o caminho para o futuro reconhecimento de um líder político.” (LIMA, I999, p. 2).

Mesmo com suas limitações, a legislação brasileira sobre eleições era uma das mais liberais da época, se comparada às europeias. Nas eleições primárias, como consequência do liberalismo de nossa Constituição, grande número de pessoas votava. Em I872, o número de votantes chegou a um milhão, correspondendo a I3\% da população livre. (CARVALHO, 1996, p. 342-343).

Esse percentual de votantes seria, em tese, um dos caminhos para a construção da cidadania. Entretanto, novatos no exercício do voto, os cidadãos não tinham, inicialmente, noção do que fosse um governo representativo, e do que significava o seu voto. Poucos eram os que estavam inteirados do novo sistema político.

Gradativamente, os eleitores perceberam que o direito ao voto era um recurso de poder a seu dispor. Em alguma medida, isso conferiu a eles uma capacidade de barganha. A renovação da história política, em boa medida se servindo dos aportes da história da cultura, é instrutiva na compreensão desse processo. (BERSTEIN, 1998). Por mais desiguais 
que fossem - e esse aspecto não pode ser negligenciado - as relações entre o líder e liderado, o candidato e o eleitor, mediadas pelo voto, revelavam um jogo social e político complexo, em que o poder não se localiza apenas em um dos polos, mas se revela e se efetiva na própria relação.

Assim, os eleitores eram sujeitos ativos do sistema. "O que estava em jogo não era o exercício de um direito de cidadão, mas o domínio político local", ou seja, "O voto neste caso não era mais expressão de obediência e lealdade, era mercadoria a ser vendida pelo melhor preço." (CARVALHO, 2008, p. 32-36). O mais importante, como observa Carvalho, "não é discutir se existiu ou se existe dominação. Ninguém nega isto. O problema é detectar a natureza da dominação." (CARVALHO, 1997, p. 6).

O clientelismo era um dos fundamentos daquela dominação e um dos obstáculos ao avanço da cidadania plena. No entanto, isso não equivale a dizer que todas as portas estavam fechadas. O caminho é, obviamente, longo, mas, ainda que por "vias tortas", a exemplo do uso do voto como mercadoria, os cidadãos iam encontrando brechas para se fazerem reconhecidos como agentes no cenário político.

\section{Referências}

APMOMG. Arquivo Público Municipal Olympio Michael Gonzaga. Livro de qualificação de votantes. Sala 4, Estante 5, Prateleira I Cx I, Maço 2.

APMOMG. Arquivo Público Municipal Olympio Michael Gonzaga. Inventário. Sala I, Estante 7, Prateleira 4 Cx I-2I, Ia Vara.

BRASIL. Constituição Política do Imperio do Brazil, de 25 de março de I824. Disponível em <"htpp://www.planalto.gov.br/civil_03/constituição/constitui\%CA7ao24.htm"\}>. Acesso em I3 ago.20IO.

BRASIL. Decreto $\mathrm{n}^{\mathrm{o}}$ 6097, de I2 de janeiro de I876. Manda observar as instruções regulamentares para execução do Decreto no 2675 de 20 de outubro de I875. Coleção das Leis do Império do Brazil, Rio de Janeiro, v. I, p. 69-I35, I876.

BRASIL. Tribunal Superior Eleitoral. Glossário eleitoral. Cf.: $<$ http://www.tse.jus.br/hotSites/glossario-eleitoral/termos/lei_do_terco.htm $>$. Acesso em 25 mai. 20II.

BAHIA, L. H. N.. O poder do clientelismo: raizes e fundamentos da troca política. Rio de Janeiro: Renoyar, 2003. Resenha de: D’AVILA F., Paulo M. O Clientelismo como Gramática Política Universal. PHYSIS: Rev. Saúde Coletiva, Rio de Janeiro, I3(2): I49-I54, 2003. Disponível em: 
<http://www.scielo.br/scielo.php?pid=SoI03-73312003000200009\&script=sci_arttext $>$. Acesso em o6 mai. 2011.

BERSTEIN, Serge. Cultura política. In: RIOX, Jean-Pierre \& SIRINELLI, Jean-François (org.). Para uma História Cultural. Lisboa: Estampa, 1998.

BICALHO, Maria Fernanda. Dos “Estados nacionais" ao "sentido da colonização": história moderna e historiografia do Brasil colonial. In: ABREU, Martha, SOIHET, Rachel e GONTIJO, Rebeca (orgs). Cultura Politica e Leituras do Passado: Historiografia e Ensino de História. Rio de Janeiro: Civilização Brasileira, 2007.

CARVALHO, José Murilo de. Cidadania no Brasil: o longo caminho. Io ${ }^{a}$ edição. Rio de Janeiro: Civilização Brasileira, 2008.

. Cidadania: tipos e percursos. Estudos Históricos, Rio de Janeiro, n. I8, p. 337-359, 1996.

Disponível em: https:/virtualbib.fgv.br/ojs/index.php/reh/article/download/2029/II68. Acesso em: 13 ago. 2010.

Mandonismo, Coronelismo, Clientelismo: Uma Discussão Conceitual. Dados, Rio de $\begin{array}{llllll}\text { Janeiro, } & \text { v. } 40,497 . & \mathrm{n}^{\circ} & 2, & \text { Disponível } & \text { em: }\end{array}$ $<$ http://www.scielo.br/scielo.php?script=sci_arttext\&pid=SooII52581997000200003\&lng=pt\&nrm=iso >. Acesso em: 2I set. 2010.

CASAL, Aires de. Corografia brasílica. Belo Horizonte: Itatiaia; São Paulo: EDUSP, 1976.

CHALHOUB, Sidney. Solidariedade e liberdade: sociedades beneficentes de negros e negras no Rio de Janeiro na segunda metade do século XIX. In: CUNHA, Olívia M. G. da e GOMES, Flávio (orgs.). Quase-cidadão: histórias e antropologias da pós-emancipação no Brasil. Rio de Janeiro: FGV, 2007, pp. 219-240.

CUNHA, Alexandre Mendes. Patronagem, clientelismo e redes clientelares: a aparente duração alargada de um mesmo conceito na história política brasileira. História, São Paulo, v. 25, $\mathrm{n}^{\circ} \mathrm{I}, \quad \mathrm{pp}$ 226-247, 2006. Disponível em: $<$ http://www.scielo.br/scielo.php?script=sci_arttext\&pid=SoIOI90742006000I00oII\&lng=pt\&nrm=iso\&tlng=pt\#tx>. Acesso em: I2 fev. $20 I I$. FERRARO, Alceu R., KREIDLOW, Daniel. Analfabetismo no Brasil: configuração e gênese das desigualdades regionais. Revista Educação \& Realidade, Porto Alegre, v. 29, n. 2, I79-200, 2004 .

Disponível em:

<http://seer.ufrgs.br/educacaoerealidade/article/viewFile/2540I/I4733>. Acesso dez 2012. GONZAGA, Olympio. Memória histórica de Paracatu. Uberaba: Typ. Jardim \& Comp, I9ı. 
GOUVÊA, Maria de Fátima Silva. Redes de Poder na América Portuguesa - O Caso dos Homens Bons do Rio de Janeiro, ca. I790-I822. Revista Brasileira de História. São Paulo, v. I8 n. 36, pp. 297-330, 1998

GRAHAM, Richard. Clientelismo e política no Brasil do século XIXI. Rio de Janeiro: Editora UFRJ, 1997 .

GRAHAM, Richard. Clientelismo e Política no Brasil do Século XIX. Rio de Janeiro: Editora da UFJR, 1997. Resenha de: LIMA, I. S. Revista Mana, v. 5, n. 2, Rio de Janeiro, out. I999. Disponível em: $\quad<$ http://www.scielo.br/scielo.php?script=sci_arttext\&pid=SoIO4931319990002000Io\&lng=pt\&nrm=iso $>$. Acesso em: 25 mai. $201 \mathrm{I}$.

HOBSBAWN, Eric, RANGER, Terence (org.) A Invenção das Tradições. $2^{\mathrm{a}}$ ed. São Paulo: Paz e Terra, 1997.

HOLANDA, Sérgio Buarque de. Raízes do Brasil. 26ª ed. São Paulo: Companhia das Letras, 2010.

JANOTTI, Maria de Lourdes Monaco. Coronelismo: uma política de compromissos. São Paulo: Brasiliense, I98I.

MARSHALL, T. H. Cidadania e Classe Social. Brasília: Fundação Projeto Rondon, 1988.

MATTOS, Hebe Maria. Escravidão e cidadania no Brasil monárquico. Rio de Janeiro: Jorge Zahar Editor, 2000.

. Raça e cidadania no crepúsculo da modernidade escravista no Brasil. In: GRINBERG, Keila; SALLES, Ricardo. O Brasil Imperial - vol. III, I870-I889. Rio de Janeiro: Civilização Brasileira, 2009.

MELlO, Oliveira. As Minas Reveladas: Paracatu no Tempo. Edição da Prefeitura de Paracatu, 1994 .

MONTEIRO, Hamilton M. Brasil Império. São Paulo: Editora Ática, 1986.

NEVES, Lucia M. B. P. das. Constituição: usos antigos e novos de um conceito no Império do Brasil (I82I-I860). In: CARVALHO, José Murilo de; NEVES, Lúcia M. B. Pereira das (orgs.). Repensando o Brasil do Oitocentos: cidadania, política e liberdade. Rio de Janeiro: Civilização Brasileira, 2009.

PESAVENTO, Sandra Jatahy. História \& História Cultura. $2^{\mathrm{a}}$ ed. Belo Horizonte: Autêntica, 2003.

QUEIROZ, Maria Isaura Pereira. O coronelismo numa interpretação sociológica. In: FAUSTO, Bóris (org.). História Geral da Civilização Brasileira. O Brasil Republicano - Estrutura de poder e economia (I889-I930). São Paulo, Difel, T. III, V. I, I975. 
SILVA, José Bonifácio de Andrada e. A abolição. Reimpressão de um opúsculo raro de José Bonifácio sobre a emancipação dos escravos no Brasil. Representação à Assembléia Geral Constituinte e Legislativa do Império do Brasil sobre a escravatura. Rio de Janeiro: tipografia Lombaerts e Comp., I884. Disponível em: <http://www.brasiliana.usp.br/bbd/handle/ı918/oI688Ioo\#page/ı2/mode/Iup>. Acesso em: 23 out. 2010.

VELLASCO, Ivan de Andrade. Clientelismo, ordem privada e Estado no Brasil oitocentista: notas para um debate. In: CARVALHO, J. M de, NEVES, L. M. B. P. das (orgs). Repensando o Brasil do Oitocentos - Cidadania, Política e Liberdade. Rio de Janeiro: Civilização Brasileira, 2009, pp. 7I-IOO.

WEBER, Max. Economia e Sociedade: fundamentos da sociologia compreensiva. Brasília: UnB, 1999, vol. 2 